\title{
Internet Addiction among Secondary School Students in Klang Valley, Malaysia: What is the Association with Depressive Symptoms, Anxiety Symptoms, and Self- Esteem?
}

\author{
Abdul Aziz $M^{a}$, Wan Ismail WS ${ }^{b}$, Bahar $N^{c}$, Mahadevan $R^{b}$, Azhar Shah $S^{d}$ \\ ${ }^{a}$ Department of Psychiatry and Mental Health, Ampang Hospital, Malaysia \\ ${ }^{b}$ Department of Psychiatry, UKM Medical Centre, Malaysia \\ 'Department of Psychiatry and Mental Health, Selayang Hospital, Malaysia \\ ${ }^{d}$ Department of Community Health, National University of Malaysia
}

\section{ABSTRACT}

Introduction: Internet addiction is becoming a global problem and has been associated with mental health issues such as depression and anxiety. There is a strong need for local research, given the recent rise of mental health issues amongst children and adolescents in Malaysia, as well as lack of research in this field locally. Methods: This study assessed the prevalence of internet addiction, and its association with internetrelated factors, depressive symptoms, anxiety symptoms, and self-esteem, amongst selected secondary school students in the Klang Valley, Malaysia. In a cross-sectional study, 199 adolescents were conveniently chosen from six randomly selected secondary schools within Klang Valley. Subjects completed a demographic questionnaire, as well as Malay versions of the Internet Addiction Test (MVIAT), Children's Depression Inventory (CDI), Depression Anxiety Stress Scales-21 anxiety subscale (DASS-21) and Rosenberg Self-Esteem Scale (RSES). Multiple logistic regression analysis was carried out. Results: This study found that $49.2 \%$ of students were addicted to the internet. Significant factors associated with internet addiction were spending longer hours online during the holidays (OR 1.20, $\mathrm{Cl} 1.01$-1.35), easy access to a computer (OR 4.01, $\mathrm{Cl} 1.50$ 10.76), confiding on the internet ( $\mathrm{OR} \mathrm{4.07,} \mathrm{Cl} 1.49-11.13)$, severe level of anxiety (OR 3.63, $\mathrm{Cl} 1.04-12.73$ ) and high depression scores (OR 1.10, $\mathrm{Cl} 1.01-1.20)$. Contrary to previous studies, self-esteem was not found to be significantly associated with internet addiction. Conclusion: This study has important implications in relation to clinical practice, research, and policy-making in Malaysia.

KEYWORDS: Internet addiction, Adolescents, Depression, Anxiety, Malaysia.

\section{INTRODUCTION}

'Internet Addiction' refers to impulse control and behavioural problems relating to internet use. ${ }^{1}$ It is a significant problem among adolescents, particularly in Asian countries. ${ }^{2,3}$ A study on internet use among adolescents in various Asian countries found high prevalence of addictive and problematic internet use ranging from $13.7 \%$ in South Korea to $50.9 \%$ in Philippines. ${ }^{3}$ Interestingly, various studies

Corresponding author:

Dr Melisa Abdul Aziz

Department of Psychiatry and Mental Health, Ampang Hospital, Jalan Mewah Utara, Pandan Mewah, Ampang, 68000 Selangor

Phone number: $+603-42896000$

Tel no : $+603-42954666$

E-mail : melisa_aziz82@yahoo.com found an association between internet addiction and mental health issues such as suicidal ideation, ${ }^{4}$ depression, ${ }^{5-6}$ anxiety, ${ }^{6-7}$ and low self-esteem. ${ }^{8}$ Various mechanisms may explain the relationship between internet addiction and psychiatric symptoms. The internet is used as a means of coping $^{9}$ to escape from emotional difficulties ${ }^{10}$ such as depression and anxiety. Nevertheless, persistent use of the internet may result in addiction, leading to a vicious cycle ${ }^{10}$ and worsen psychiatric symptoms. ${ }^{9}$ Depression and anxiety may also be part of the internet withdrawal syndrome. ${ }^{6}$ Internet addiction is a growing problem among adolescents in Malaysia. Local studies have reported prevalence rates of between $2.4 \%$ and $16 \% .^{3,11}$ At the same time, mental health issues among Malaysian children and adolescents have also increased. According to the 
National Health and Morbidity Survey 2011, 20\% of Malaysian children and adolescents are afflicted with mental health problems such as depression and anxiety, compared to only $13 \%$ in $1996 .{ }^{12}$ The rise in mental health issues may contribute to, or be made worse by, internet addiction.

Understanding the coexistence of psychiatric disorders and internet addictions has significant clinical implications. From the clinical perspective, it is important that psychiatric disorders are explored in adolescents with internet addiction and vice-versa. Focusing on only one problem may result in failure of treatment. ${ }^{10}$ Given the significance, it is important to explore internet addiction among Malaysian adolescents and its association with mental health problems. This research will further facilitate our understanding of the issue in the local setting, including intervention and preventive measures in order to curb the problem among our adolescents.

This study aims to determine the prevalence of internet addiction and its association with depressive symptoms, anxiety symptoms, and selfesteem among secondary school students within Klang Valley, Malaysia.

\section{MATERIALS AND METHODS}

Six national, co-educational (consists of both male and female students) secondary schools within the Klang Valley, Malaysia, were randomly chosen via a computer randomiser programme. A total of 300 students was conveniently selected to participate and 199 students were finally recruited.

Their ages ranged between 13 to 17 years old. Inclusion criteria included students who were wellversed in Malay language, students who were not in the major exam years and students whose parents consented for them to participate. 101 students were excluded because of incomplete, illegible questionnaires, failure to return the questionnaires, and refusal to participate in the study. Written consent was taken from parents and students. Ethical approval was obtained from the university ethics committee and the Ministry of Education. Responses were anonymous. In order to increase awareness and facilitate detection, parents and students were educated regarding internet addiction, depression and anxiety among adolescents. They were also informed about the child and adolescent psychiatric services available should professional help be needed. In this crosssectional study, students completed self-reported questionnaires namely demographic questionnaire, the Internet Addiction Test (IAT), Children's Depression Inventory (CDI), Depression, Anxiety and Stress Scale-21 (DASS-21) Anxiety Subscale, and Rosenberg Self-Esteem Scale (RSS). All the questionnaires used in this study were in Malay language.

The Internet Addiction Test is a 20-item self-rated questionnaire which uses a 5-point Likert scale to assess internet addiction. ${ }^{13}$ It has been used in various studies on adolescents. ${ }^{3,14}$ The Malay IAT was found to be reliable (Cronbach's alpha 0.91 ; intraclass coefficient $0.88, \mathrm{p}<0.001$ ) and valid (Pearson's correlation $0.84, \mathrm{p}<0.001$ when concurrent validity was tested against Compulsive Internet Use Scale) when tested on Malaysian university students. ${ }^{15}$ In this study, a cutoff score of 43 was used. ${ }^{15}$

The Children's Depression Inventory (CDI) is a 27-item self-reported questionnaire to assess 5 domains of depressive symptoms in children and adolescents. ${ }^{16}$ The Malay CDI is valid as an accurate screening tool for depression amongst Malay-speaking children and adolescents, when using overall scores (when compared to clinically depressed adolescents, with a Cronbach's alpha of 0.85 for overall CDI score). ${ }^{17}$ A cutoff score of 17 was used in this study.

The Depression, Anxiety and Stress Scale-21 (DASS21 ) is widely used to assess depressive, anxiety, and stress symptoms in adults and adolescents. This study utilised the short 21 -item version ${ }^{18}$ focusing specifically on the anxiety subscale. The Malay short version of DASS was found to have good psychometric properties. ${ }^{19}$ For anxiety, the Cronbach's alpha value is 0.74 . Factor loading values ranged from 0.39 to 0.73. The higher the score, the more severe the anxiety symptoms that the respondent had, ranging from no anxiety to extreme anxiety.

The Rosenberg Self-Esteem Scale (RSES) consists of 10 items and is used to assess global self-esteem. Higher scores indicate a more positive self-esteem. ${ }^{20}$ When tested on Form 2 students in a school (average of 14 years old), the Malay RSES was found to be 
reliable (Cronbach's alpha 0.8) and valid (factor loading more than 0.4). ${ }^{21}$

Parents were asked regarding their children's internet use such as purpose of going online, places where internet was accessed from, and duration of internet use. Parents were also asked their perceptions relating to their children's internet use such as whether they spent a longer time online than was necessary, whether parents thought their child neglected role obligations at home and at school, or gave up social and recreational activities, due to internet usage.

Data were analysed using the SPSS version 22.0. The sociodemographic data and pattern of internet use were analysed using descriptive statistics. Chi square test, logistic regression and Mann Whitney $U$ tests were subsequently used. This was followed by multivariate analysis to look at the relationship between the associated factors and internet addiction.

\section{RESULTS}

From a total of 300 subjects, only 199 students were finally recruited in the study due to 101 incomplete, illegible, or unreturned questionnaires; as well as disagreement to participate in the study. The response rate was $66 \%$. The median age of participants was 16 years old. $75 \%$ of participants were female. As for race, the majority (almost 70\%) were Malays, followed by $15 \%$ Chinese and $13 \%$ Indians, whilst about $2 \%$ were from other races. This followed the trend of the Malaysian population, although the racial breakdown differed in that Malays make up $50.4 \%$ of the population, Chinese $24.6 \%$ and Indians $7.1 \% .{ }^{22}$ In our study, most students confided in their friends $(n=163)$, followed by parents $(n=120)$, siblings $(n=96)$, and the internet $(n=44)$.

For certain questions, the options were not mutually exclusive, e.g. participants were allowed to choose more than 1 answer for type of confidante. $75 \%$ of students had easy access to a computer, be it their own or shared with a sibling. Table I shows the pattern of internet-related factors among participating students. The most common reasons for using the internet were social networking, information searching, downloading, using Instant Messenger and online gaming. Most of the students accessed the internet from homes $(n=192)$ followed by no fixed place $(n=69)$, and friend's house $(n=25)$. Again, here, participants were allowed to choose more than 1 answer. The median total time of hours spent online by students during school days was three hours, and five hours during weekends.

On the other hand, parents perceived that their children's use of the internet were mainly to look for information, social networking, and online gaming. Parents generally agreed with students with regards to places of internet use. Parents perceived lesser time spent online (median 2 hours on weekdays) compared to the time reported by students (median 3 hours on weekdays). Over half of the parents believed that their children spent a longer time online than was necessary. Over a third of parents reported that their children's internet usage interfered with his or her role obligations at home or at school, but only $18 \%$ thought that their children gave up social or recreational activities because of internet use.

Prevalence of internet addiction was $49.2 \%$. $21.6 \%$ of the students had a high likelihood of having depression whilst $65.3 \%$ had anxiety symptoms of different severity. Most of the students reported moderate self-esteem (64.3\%), while $18.6 \%$ had high self-esteem and $17.1 \%$ had low self-esteem.

Table II shows the multivariate analysis of factors associated with internet addiction. Five significant factors were hours spent online during non-school days, easy access to a computer, confiding to others online, severe anxiety, and higher depression scores on the CDI.

\section{DISCUSSION}

Prevalence rates of internet addiction among adolescents ranged between $1.4 \%$ to $17.9 \% .{ }^{23}$ This can be attributed to the different instruments used, different cutoff points of similar instruments ${ }^{24}$ and variations in internet accessibility. ${ }^{25}$

Our prevalence rate of $49.2 \%$ was alarming, but needs cautious interpretation, particularly when participants were not randomly but conveniently sampled. A local study found $3.3 \%$ of secondary school students were excessive internet users, whilst $54.2 \%$ were moderate internet users. ${ }^{14}$ 
Table I: Internet-related factors among participating students

\begin{tabular}{lc}
\hline Characteristic & $\mathbf{n}(\%)$ \\
\hline Type of application used $^{*}$ & $52(7.2 \%)$ \\
Email & $80(11.1 \%)$ \\
Instant messenger & $164(22.8 \%)$ \\
Social networking & $31(4.3 \%)$ \\
Blogs & $55(7.6 \%)$ \\
Discussion groups/Forum & $76(10.6 \%)$ \\
Game website & $31(4.3 \%)$ \\
Online shopping & $72(10.0 \%)$ \\
Downloading & $159(22.1 \%)$ \\
Looking for information & \\
& \\
\hline Place internet accessed from & \\
Cybercafe & $10(3.3 \%)$ \\
Library & $4(1.3 \%)$ \\
Home & $192(62.7 \%)$ \\
Friend's house & $25(8.1 \%)$ \\
At school & $6(2.0 \%)$ \\
No fixed place & $69(22.5 \%)$
\end{tabular}

Parents' perception -

Type of application used by student*

Email

$58(8.0 \%)$

Instant messenger

$69(9.5 \%)$

Social networking

$153(21.1 \%)$

Blogs

$28(3.9 \%)$

Discussion groups/Forum

$70(9.6 \%)$

Game website

$88(12.1 \%)$

$30(4.1 \%)$

$67(9.2 \%)$

Ontine shopping

$163(22.5 \%)$

Parents' perception -

Place internet accessed*

Cybercafe

$7(2.4 \%)$

Library

$3(1.0 \%)$

Home

Friend's house

$186(64.6 \%)$

At school

$14(4.9 \%)$

$5(1.7 \%)$

No fixed place

$73(25.3 \%)$

Parents' perception:

Child spends longer than neces-

$102(51.3 \%)$

sary online.

Child's usage interferes with role

$73(36.7 \%)$

obligations.

Child gives up social/recreational $36(18.1 \%)$

activities.

\begin{tabular}{ll}
\hline Characteristic & Median (IQR) \\
\hline Hours spent online & $3.0 \mathrm{hrs}(2.0-5.0)$ \\
School days & $5.0 \mathrm{hrs}(3.0-10.0)$ \\
Holidays & \\
\hline $\begin{array}{l}\text { Parents' perception - } \\
\text { Hours spent online by student }\end{array}$ & \\
School days & $2.0 \mathrm{hrs}(1.0-4.0)$ \\
Holidays & $5.0 \mathrm{hrs}(3.0-8.0)$ \\
\hline
\end{tabular}

$\mathrm{IQR}$ = inter-quartile range

*may answer more than 1 option
Table 2: Multivariate analysis of relationship of Internet Addiction with associated factors, among participating students

\begin{tabular}{|c|c|c|c|c|c|}
\hline Variable & B & S.E. & Sig. & $\begin{array}{l}\text { Exp } \\
\text { (B) }\end{array}$ & $\begin{array}{l}95 \% \\
\text { C.I. }\end{array}$ \\
\hline $\begin{array}{l}\text { Age } \\
(16 / 17 \text { vs } \\
13-15)\end{array}$ & 0.50 & 0.40 & 0.211 & 1.65 & $\begin{array}{l}0.75 \\
3.63\end{array}$ \\
\hline $\begin{array}{l}\text { Confidante: } \\
\text { Parent (no vs } \\
\text { yes) }\end{array}$ & 0.52 & 0.40 & 0.189 & 1.66 & $\begin{array}{l}0.78 \\
3.64\end{array}$ \\
\hline $\begin{array}{l}\text { Confidante: } \\
\text { Internet (yes } \\
\text { vs no) }\end{array}$ & 1.40 & 0.51 & 0.006 & 4.07 & $\begin{array}{l}1.49 \\
11.13\end{array}$ \\
\hline $\begin{array}{l}\text { Confidante: } \\
\text { Friend } \\
\text { (yes vs no) }\end{array}$ & 0.70 & 0.54 & 0.201 & 2.01 & $\begin{array}{l}0.69 \\
5.82\end{array}$ \\
\hline $\begin{array}{l}\text { Grades } \\
\text { (poor vs good) }\end{array}$ & 0.33 & 0.43 & 0.442 & 1.39 & $\begin{array}{l}0.60 \\
3.24\end{array}$ \\
\hline $\begin{array}{l}\text { Academic } \\
\text { performance } \\
\text { (worse vs } \\
\text { better/same) }\end{array}$ & 0.53 & 0.58 & 0.362 & 1.67 & $\begin{array}{l}0.54 \\
5.29\end{array}$ \\
\hline $\begin{array}{l}\text { Easy access to } \\
\text { computer (yes } \\
\text { vs no) }\end{array}$ & 1.39 & 0.50 & 0.006 & 4.01 & $\begin{array}{l}1.50 \\
10.76\end{array}$ \\
\hline $\begin{array}{l}\text { Health } \\
\text { (poor vs good) }\end{array}$ & 0.20 & 0.44 & 0.643 & 1.23 & $\begin{array}{l}0.52 \\
2.91\end{array}$ \\
\hline $\begin{array}{l}\text { Family } \\
\text { income } \\
(>\mathrm{RM} 10,000) \\
\left({ }^{*} \mathrm{ref}\right) \\
(<\mathrm{RM} 2,000)\end{array}$ & 0.91 & 0.84 & $\begin{array}{l}0.043 \\
0.277\end{array}$ & 2.49 & 0.48, \\
\hline (RM2,001- & 1.12 & 0.71 & 0.112 & 3.07 & $\begin{array}{l}12.84 \\
0.77, \\
1274\end{array}$ \\
\hline $\begin{array}{l}(\mathrm{RM}, 001- \\
10,000)\end{array}$ & -0.26 & 0.66 & 0.693 & 0.77 & $\begin{array}{l}0.21 \\
2.81\end{array}$ \\
\hline $\begin{array}{l}\text { Social } \\
\text { Networking } \\
\text { (yes vs no) }\end{array}$ & 0.94 & 0.56 & 0.097 & 2.56 & $\begin{array}{l}0.85 \\
7.71\end{array}$ \\
\hline $\begin{array}{l}\text { Online } \\
\text { shopping } \\
\text { (yes vs no) }\end{array}$ & 0.45 & 0.62 & 0.465 & 1.57 & $\begin{array}{l}0.47 \\
5.29\end{array}$ \\
\hline $\begin{array}{l}\text { Blogging } \\
\text { (yes vs no) }\end{array}$ & 0.48 & 0.62 & 0.378 & 1.62 & $\begin{array}{l}0.55 \\
4.75\end{array}$ \\
\hline $\begin{array}{l}\text { Discussion/ } \\
\text { forum } \\
\text { (yes vs no) }\end{array}$ & -0.35 & 0.48 & 0.467 & 0.70 & $\begin{array}{l}0.27 \\
1.82\end{array}$ \\
\hline $\begin{array}{l}\text { Downloading } \\
\text { (yes vs no) }\end{array}$ & -0.40 & 0.48 & 0.398 & 0.67 & $\begin{array}{l}0.26 \\
1.70\end{array}$ \\
\hline Total CDI** & 0.09 & 0.05 & 0.045 & 1.10 & $\begin{array}{l}1.01 \\
1.20\end{array}$ \\
\hline
\end{tabular}




\begin{tabular}{|c|c|c|c|c|c|}
\hline Variable & $\bar{B}$ & S.E. & Sig. & $\begin{array}{l}\operatorname{Exp} \\
(B)\end{array}$ & $95 \%$ C.I. \\
\hline No anxiety & & & 0.211 & & \\
\hline Extreme & -0.51 & 0.68 & 0.458 & 0.60 & $0.16,2.29$ \\
\hline anxiety & 1.29 & 0.64 & 0.044 & 3.63 & $1.04,12.73$ \\
\hline $\begin{array}{l}\text { anxiety } \\
\text { Moderate }\end{array}$ & 0.24 & 0.53 & 0.645 & 1.27 & $0.45,3.57$ \\
\hline Mild anxiety & 0.38 & 0.64 & 0.553 & 1.46 & $0.42,5.15$ \\
\hline $\begin{array}{l}\text { High self- } \\
\text { esteem } \\
\text { (*ref) }\end{array}$ & & & 0.583 & & \\
\hline Low self- & 0.52 & 0.80 & 0.519 & 1.67 & $0.35,7.99$ \\
\hline $\begin{array}{l}\text { Moderate } \\
\text { self-esteem }\end{array}$ & -0.12 & 0.54 & 0.828 & 0.89 & $0.31,2.57$ \\
\hline $\begin{array}{l}\text { Mother's } \\
\text { occupation } \\
\text { (professiona } \\
\text { l'vs not) }\end{array}$ & 0.98 & 0.54 & 0.070 & 2.67 & $0.92,7.75$ \\
\hline $\begin{array}{l}\text { Hours online } \\
\text { school } \\
\text { days }^{* *}\end{array}$ & -0.91 & 0.11 & 0.420 & 0.91 & $0.73,1.14$ \\
\hline $\begin{array}{l}\text { Hours online } \\
\text { holidays }^{* *}\end{array}$ & 0.16 & 0.06 & 0.003 & 1.20 & $1.07,1.35$ \\
\hline
\end{tabular}

Another study comparing internet addiction in six Asian countries found $35.1 \%$ of the study samples were problematic internet users while only $2.4 \%$ of the Malaysian students were internet addicts. ${ }^{3}$ However the studies mentioned used different languages i.e. English version; ${ }^{14}$ and a combination of English, Malay and simplied Chinese versions. ${ }^{3}$ Our study used the Malay version, which meant those with poor understanding of Malay would be excluded and this may have affected the results. Also, both studies had used different cutoff points.

So, is internet addiction increasing among adolescents in Malaysia or is it due to other factors such as different languages, different cutoff points, as well as different locations of sampling? While the comparison is difficult, it is possible that prevalence of internet addiction is actually increasing among the adolescents in our country. Higher numbers of Malaysian population have access to the internet given the high penetration rates, ${ }^{26}$ particularly in urban areas. Most houses now have internet access from their computers, or readily accessible internet through various gadgets such as tablets and mobile phones. Unlike Korea, ${ }^{27}$ there is no restriction in internet access at the national level, hence the ready availability of internet at all times. Parental monitoring becomes an important factor that controls access and use of internet among adolescents. ${ }^{28}$ In Malaysia, particularly in urban areas, both parents work to meet their needs. ${ }^{29}$ In such situations, adolescents may be left unsupervised at home. Lack of parental monitoring as well as allowance of more than 2 hours of internet use per day, has been shown to lead to internet addiction. ${ }^{30}$ This may explain the high prevalence among adolescents in this study, although individual and peer factors should also be taken into consideration. ${ }^{31}$

Mental health issues are also on the rise among Malaysian children and adolescents, ${ }^{32}$ which could contribute further to the higher prevalence of internet addiction in our study, or vice-versa.

Our study had demonstrated significant associations between internet addiction and hours spent online during non-school days, easy access to a computer, and the behaviour of confiding to others online.

Students with internet addiction spent twice the amount of time online during weekends compared to non-addicts. Asian studies found that the amount of time an adolescent spent online was significantly associated with internet addiction. ${ }^{33-34}$ Possibly, parents allowed more internet use during weekends since it was less likely to interfere with school work.

Easy access to a computer was also significant in association with internet addiction. This is understandable given that most of the students in our study had easy access to the internet from home whilst 22.5\% had access from mobile phones. Household broadband penetration in Malaysia had reached $67.1 \%$ in 2013, which had seen an exponential increase over the years. ${ }^{26}$ Malaysia has been ranked first in terms of broadband affordability as compared to 45 other developing nations. ${ }^{26}$ Similar findings were seen in 5 countries across Asia, namely, Malaysia, Hong Kong, Japan, South Korea, and China. ${ }^{3}$

Students who owned a computer or shared one with a sibling were four times more likely to have an internet addiction compared to those who did not own a computer, and this was statistically significant. This was a logical expectation as, for students who had difficulty accessing a device with internet, perhaps their parents acted as gatekeepers and set passwords for internet access, or had tighter restrictions on internet usage. For those who had their own computers, there was easier access and relatively less monitoring by parents. 
With the increased hours spent online, it would not be surprising that the adolescent would be more likely to confide to others online. The behaviour of confiding to others online was significantly associated with internet addiction. Malaysian youth have the most friends online such as Facebook, ${ }^{35}$ as compared to other developed countries. ${ }^{36}$

Our adolescents possibly went online to fulfil their unmet needs in the real world, for example, a lack of close confiding relationships in real life, subsequently attach great importance to these personal relationships and becoming more willing to disclose their personal matters online. ${ }^{37}$ In fact, the act of revealing personal information to others is one of the features of internet-based behaviour. ${ }^{38}$ Pathological internet users were found to have shared more intimate secrets on the internet, when compared to normal users. ${ }^{39}$ As the confiding behaviour continues, they are less motivated to find confidantes in real life. Coupled with the easy availability and feature of anonymity of the internet, it becomes an attractive outlet indeed for frequent internet users to share their personal matters.

Similar to previous studies, ${ }^{2,8,9,40}$ our study showed a significant association between internet addiction and high level of depression and anxiety among adolescents. Adolescents with mental health issues might use the internet as an escapism from everyday problems. ${ }^{41}$ South Korean high school students were found to use the internet to alleviate negative moods that arose from discrepancies between their "real selves" and their "ideal selves". ${ }^{42}$ Socially anxious adolescents are attracted to the internet due to its reduced visual and auditory cues, which might cause anxiety in reallife communication. ${ }^{43-44}$ Thus, adolescents with high levels of anxiety probably felt protected in an environment they had more control over, using the internet for social communication, without the need to reveal their true identity or physical self. They also had the added ability to control information they divulged online. ${ }^{45}$

On the other hand, adolescents with depressive and anxiety symptoms may also attempt to seek emotional support online. A local study showed that the prevalence of secondary school students seeking help on the internet for emotional problems was $30.4 \%{ }^{46}$
From another viewpoint, internet addiction itself could predispose adolescents to mental health issues, although this study could not establish a causal relationship because of its cross-sectional nature. As the adolescent spends longer hours than necessary online, social ties are neglected leading to high level of loneliness and smaller social circles, ${ }^{47}$ which may lead to depression. Frequent internet users had reported more depression than infrequent users. ${ }^{48}$

Adolescents with low self-esteem also had the tendency to develop an addiction to the internet. ${ }^{35}$ They may use the internet as a way to cope or escape from negative self-evaluation, as the disinhibitory effects can be liberating. ${ }^{39}$ However, in our study, low self-esteem lost its significance after multivariate analysis. This could be due to the small sample size. Possibly, also, the online communication had encouraged social ties and wellbeing, ${ }^{49}$ whereby psychological well-being is linked to self-esteem. ${ }^{50}$

\section{CONCLUSION}

In summary, as the internet becomes an increasingly pervasive part of the adolescent's life, mental health professionals will have to include it as a tool for assessment of behaviour. ${ }^{38}$ Implications of our findings include the need for early detection of depressed or anxious students by teachers, school counselors, and parents, before the troubled teenager transcends deeper into the addictive world of the internet. It has been noted that unrecognized internet addiction as a comorbidity in anxious or depressed patients can give rise to poor response to therapy and poor outcomes. ${ }^{51}$ Positive coping strategies, e.g. knowing how to get access to good social support online, can buffer the negative impact of stressful life events to temporarily reduce levels of anxiety and stress. ${ }^{52}$

To reduce the amount of time spent online, adolescents' access to the internet should be controlled. Parents can play their part by monitoring their children's internet use. As demonstrated by our study, the hours spent online during weekends played a much bigger role in having an internet addiction than hours spent online during school days. Thus, as part of the management, parents would need to monitor their children more closely during non-schooling days as well. Parents should also foster stronger parent- 
adolescent relationship, which would encourage the adolescent to confide in their parents. The government can emulate countries which have been successful in reducing prevalence rates of internet addiction via compulsory policies for internet providers to limit adolescents' time online. ${ }^{3,27}$ Finally, adolescents themselves should be made aware of the dangers of inappropriate behaviour such as divulging confidential matters and personal details online, as it can lure stalkers and sexual predators that lurk behind the safety of anonymity, and also predispose the teenager to cyber bullying.

\section{ACKNOWLEDGEMENTS}

\section{Author Disclosure Statement}

The principal author received funding from UKM Medical Centre for purchase of 300 copies of Malay version of Children's Depression Inventory for the purpose of this study.

No competing financial interests exist.

\section{REFERENCES}

1. Young KS. Internet addiction: evaluation and treatment. Student British Medical Journal 1999; 7: 351-352.

2. Ha, JH, Yoo, HJ, Cho IH, Chin B, Shin D, Kim JH. 2006. Psychiatric comorbidity assessed in Korean children and adolescents who screen positive for internet addiction. Journal of Clinical Psychiatry 2006; 67 (5): 821-6.

3. Mak KK, Lai CM, Watanabe $\mathrm{H}$, et al. Epidemiology of internet behaviors and addiction among adolescents in six Asian countries. Cyberpsychology, Behavior and Social Networking 2014; 17 (11): 720-728.

4. Yoo YS, Cho OK, Cha KS. Associations between overuse of the internet and mental health in adolescents. Nursing and Health Sciences 2014; 16: 193-200.

5. Fu KW, Chan WSC, Wong PWC, Yip PSF. Internet addiction: prevalence, discriminant validity and correlates among adolescents in Hong Kong. The British Journal of Psychiatry 2010; 196: 486-492.

6. Ho RC, Zhang MWB, Tsang TY, et al. The association between internet addiction and psychiatric co-morbidity: a meta-analysis. BioMed Central Psychiatry 2014; 14:183.

7. Tang J, Yu Y, Du Y, Ma Y, Zhang D, Wang J. Prevalence of internet addiction and its association with stressful life events and psychological symptoms among adolescent internet users. Addictive Behaviors 2014; 39 (3): 744-747.

8. Lee MS, Oh EY, Cho SM, Hong MJ, Moon JS. An assessment of adolescent internet addiction problems related to depression, social anxiety and peer relationship. Journal of the Korean Neuropsychiatry Association 2001; 40 (4): 616626.

9. Yen JY, Ko CH, Yen CF, Chen SH, Chung WL, Chen CC. Psychiatric symptoms in adolescents with Internet addiction: comparison with substance use. Psychiatry and Clinical Neurosciences 2008; 62 (1): 9-16.

10. Ko CH, Yen JY, Yen CF, Chen CS, Chen CC. The association between Internet addiction and psychiatric disorderL a review of the literature. Eur Psychiatry 2012; 27(1): 1-8.

11. Moslehpour M, Batjargal U. Factors influencing internet addiction among adolescents of Malaysia and Mongolia. Jurnal Administrasi Bisnis 2013; 9 (2): 101-116.

12. Ministry of Health, Malaysia. National Health and Morbidity Survey 2011 [online]. Available at: http://www.moh.gov.my. Accessed June 3, 2015.

13. Young KS. (2011) Clinical assessment of internetaddicted clients. In: Young KS, de Abreu CN, eds. Internet addiction: $a$ handbook and guide to evaluation and treatment. John Wiley \& Sons, Inc. pp 19-34.

14. Yong SQ. (2011) A study of internet addiction among students of Sekolah Menengah Jenis Kebangsaan Pei Yuan, Kampar [online]. Available at: http://eprints.utar.edu.my/274/1/PY-20110802518.pdf . Accessed June 15, 2015.

15. Ng CG, Saramah MI, Aili HH, Subash KP, Manveen KHS. Validity of the Malay version of the Internet Addiction Test: A study on a group of medical students in Malaysia. Asia Pacific Journal of Public Health 2012; 27(2).

16. Kovacs M. (2003) Children's Depression Inventory, Multi-Health Systems Inc.

17. Tan SMK, Loh SF, Mohamad Adam B, et al. Validation of the Malay version of Children's Depression Inventory. International Medical Journal 2013; 20 (2): 188.

18. Lovibond, SH, Lovibond PF. (1995) Manual for the Depression Anxiety Stress Scales, Sydney.

19. Ramli M, Ariff MF, Zaini Z. Translation, validation and psychometric properties of 
Bahasa Malaysia version of the Depression Anxiety and Stress Scales (DASS- 21). ASEAN Journal of Psychiatry 2007; 8(2): 82-89.

20. Rosenberg M. (1965) Society and the adolescent self-image. Princeton, NJ, Princeton University Press.

21. Mohd Jamil BHY. Validity and reliability study of Rosenberg Self-Esteem Scale in Seremban school children. Malaysian Journal of Psychiatry 2006; 15(2): 35-39.

22. Demographics of Malaysia. Wikipedia [online]. Available at: http://en.wikipedia.org/wiki/ Demographics_of_Malaysia. Accessed May 1, 2015.

23. Ko CH, Yen JY, Chen CS, Yeh YC, Yen CF. Predictive values for psychiatric symptoms in adolescents. A 2-year prospective study. Archives of Pediatrics \& Adolescent Medicine 2009;163 (10): 937-943.

24. Young KS, De Abreu CN, eds. (2010) Internet addiction: a handbook and guide to evaluation and treatment, John Wiley \& Sons.

25. Weinstein A, Lejoyeux M. Internet addiction or excessive internet use. American Journal of Drug and Alcohol Abuse 2010; 36: 277-283.

26. Malaysian Communication and Multimedia Commission (2013). Malaysian Communication and Multimedia Commission Annual Report 2013 [online]. Available at: http:// www.skmm.gov.my/skmmgovmy/media/ General/pdf/MCMC---AR_ENG_2013.pdf . Accessed June 3, 2015.

27. Hawkins M. (2012). South Korea introduces yet another law to curb gaming's ills. NBC News [online]. Available at: http:// www.nbcnews.com/technology/south-koreaintroduces-yet-another-law-curb-gamings-ills158168 . Accessed June 15, 2015.

28. Epstein JA. The role of parents and related factors on adolescent computer use. Journal of Public Health Research 2012; 1(1): 75-78.

29. Rokis R. Work-care balance among parentsworkers in Malaysian urban organizations: role and quality of children's daycare centers. American International Journal of Social Science 2014; 3(1): 109-129.

30. Ko CH, Wang PW, Liu TL, Yen CF, Chen CS, Yen JY. Bidirectional associations between family factors and Internet addiction among adolescents in a prospective investigation. Psychiatry and Clinical Neurosciences 2015; 69: 192-200.
31. 31. Wu X, Chen X, Han J, et al. 2013. Prevalence and factors of addictive internet use among adolescents in Wuhan, China: Interactions of parental relationship with age and hyperactivity-impulsivity. PLoS ONE 8(4): e61782. Available at: https://doi.org/10.1371/ journal.pone.0061782. Accessed August 27, 2017.

32. Ahmad NA, MuhdYusoff F, Ratnasingam S, et al. Trends and factors associated with mental health problems among children and adolescents in Malaysia. International Journal of Culture and Mental Health 2015, 8(2), 125136.

33. Hur MH. Demographic, habitual, and socioeconomic determinants of Internet addiction disorder: an empirical study of Korean teenagers. CyberPsychology \& Behavior 2006; 9(5): 514-525.

34. Yang SC, Tung CJ. Comparison of internet addicts and non-addicts in Taiwanese high school. Computers in Human Behavior 2007; 23 (1): 79-96.

35. Balakrishnan V, Azra S. Malaysian Facebookers: Motives and addictive behaviours unraveled. Computers in Human Behavior 2013; 29(4): 1342-1349.

36. Lewis J, West A. Friending: London-based undergraduates experience of Facebook. New Media and Society 2009; 11 (7): 1209-1229.

37. Bellamy A, Hanewicz C. An exploratory analyses of the social nature of Internet addiction: $A$ research paper submitted to the Electronic Journal of Sociology 2001; 5(3).

38. Joinson AN. Self-disclosure in computermediated communication: the role of selfawareness and visual anonymity. European Journal of Social Psychology 2001; 31: 177-192.

39. Niemz K, Girffiths M, Banyard P. Prevalence of pathological internet use among university students and crrelations with self-esteem, the General health Questionnaire (GHQ), and disinhibition. CyberPsychology \& Behavior 2205; 8(6): 562-570.

40. Cao F, Su L. Internet addiction among Chinese adolescents: prevalance and psychological features. Child Care, Health and Development 2007; 33(3): 275-281.

41. Young KS. Internet addiction: the emergence of a new clinical disorder. CyberPsychology and Behavior 1998; 1(3): 237-244.

42. Kwon JH, Chung CS, Lee J. The effects of 
escape from self and interpersonal relationship on the pathological use of internet games.

Community Mental Health Journal 2011; 47:

113-121.

43. Shouten AP, Valkenburg PM, Peter J.

Precursors and underlying processes of adolescents' online self-disclosure: developing and testing an "Internet-attribute-perception" model. Media Psychology 2007; 10: 292-314.

44. Valkenburg PM, Peter J. Online communication and adolescents' well-being: testing the stimulation versus the displacement hypothesis. Journal of Computer Mediated Communications 2007; 12(4): article 2.

45. Amichai-Hamburger $Y$, Wainapel G, Fox S. "On the internet no one knows I'm an introvert": extraversion, neuroticism, and internet interaction. CyberPsychology \& Behavior 2002; 5(2): 125-129.

46. Tuti Iryani, MD. (2005). Seeking help on the internet: a study among Form Four secondary school students in Kuala Lumpur. Universiti Kebangsaan Malaysia.

47. Nie NH, Hillygus DS, Erbring L. (2002) Internet use, interpersonal relations, and sociability: a time diary study. In: Wellman B, Haythornwaite $\mathrm{C}$, eds. The internet in everyday use. Oxford, Blakcwell: 215-243.

48. Bessiere K, Kiesler S, Kraut R, Boneva B. Effects of internet use and social resources on changes in depression. Information, Communication and Society 2008; 11: 47-70.

49. Kraut R, Kiesler S, Boneva B, Cummings J, Helgeson V, Crawford A. 'Internet paradox revisited'. Journal of Social Issues 2002: 58(1): 49-74.

50. Neff KD. Self-compassion, self-esteem and well -being. Social and Personality Psychology Compass 2011; 5(1): 1-12.

51. Pies R. Should DSM-V designate "Internet Addiction" a mental disorder? Psychiatry (Edgmont) 2009; 6 (2): 31-37.

52. Leung L. Stressful life events, motives for internet use, and social support among digital kids. CyberPsychology \& Behavior 2007; 10(2): 204-214. 
